\title{
Early Employment Outcomes of College Graduates of Diverse Economic Status
}

\author{
Ching-Ling $\mathrm{Wu}$ (Corresponding author) \\ National Chi Nan University, Taiwan \\ E-mail: clwu@ncnu.edu.tw
}

Mau-Ly Pham

National Chi Nan University, Taiwan

E-mail: phamthimauly@gmail.com

Received: October 28, 2016

Accepted: November 15, 2016 Published: December 14, 2016

doi:10.5296/ire.v5i1.10111

URL: http://dx.doi.org/10.5296/ire.v5i1.10111

\begin{abstract}
A college degree used to open doors for job, particularly for socioeconomically disadvantaged graduates. However, college graduates are experiencing increasing difficulties in the labor market and graduate employment has emerged as a hotly debated issue. This study employed a nationally representative sample from 140 colleges around Taiwan to compare early employment outcomes (job opportunity, salary, and job satisfaction) of graduates of diverse economic status and to examine related factors. The results revealed that graduate salary and job satisfaction corresponded to their economic status. Being female or technical institute graduate enhanced job opportunities, but hindered salaries for all graduates. Collegiate experiences enhanced job opportunities particularly for graduates of low economic status, and degree-level expertise enhanced salary and job satisfaction for all graduates. Based on the results, this study proposes institutional interventions specifically tailored for graduates of different economic status.
\end{abstract}

Keywords: Job opportunity, Salary, Job satisfaction, College graduates, Economic status

\section{Introduction}

The International Labor Organization (ILO) has warned that the youth employment crisis, although slowly recovering, is far from over. In 2014, the global youth (ILO defines youth as those between the ages of 15 and 24) unemployment rate remained 13.0\%, an approximately equivalent of 73.3 million unemployed youths worldwide. Youth are strongly overrepresented 
among the unemployed; with $36.7 \%$ of the global unemployed were youth (ILO, 2014). Among the employment crisis, the increasing difficulties encountered by college graduates in the labor market have attracted particular attention (Brown et al., 2004). In contrast to the notion that a college degree opens doors for better employment, statistics show that college graduates are less competitive than the less educated in the labor market. In Taiwan, a breakdown of the 2015 national unemployment rate revealed a significantly higher unemployment rate for college graduates than for the less educated (Directorate General of Budget of Taiwan, 2015). Employment issues of college graduates have generated great concern and considerable debate for students, parents, educators, scholars, and numerous other parties.

In this knowledge economy era, college plays a vital role in cultivating employable industry professionals (Rahman et al., 2011). A smooth transition from school to the workplace is a shared goal among the aforementioned interest parties (Kruss, 2004). In the school-to-work transition, the early employment outcomes is a crucial junction which provides rich information to the interest parties, because it backward links to collegiate educational experiences and forward links to ultimate career success (Freund, 2011). However, a comprehensive knowledge of graduate early employment outcomes and related factors is lacking (Zimmer-Gembeck \& Mortimer, 2006).

Embedded in the widening divergence of economic stratifications in society, students of diverse economic statuses have been segregated at college (Astin \& Oseguera, 2004). Nevertheless, colleges and societies remain estranged to the different collegiate experiences of students of diverse economic status (Newton \& Turale, 2000). Among students of diverse economic status, students of low economic status were found to experience more challenges at college (Haveman \& Smeeding, 2006) and perceive less prospects after graduation (Phillips and Pittman, 2003) than their better-off counterparts. How institutes can effectively and simultaneously promote positive collegiate experiences and early employment outcomes of graduates of diverse economic status is an important question.

Based on this introduction, this study investigates the following three research questions:

(1) What are the early employment outcomes of graduates of diverse economic status?

(2) What are the gender distribution, collegiate experience, work motivation, and job characteristics of graduates of diverse economic status?

(3) How do gender, collegiate experience, work motivation, and job characteristics affect early employment outcomes of graduates of diverse economic status?

\section{Literature Review}

\subsection{Employment Outcomes and Social Capital of Graduates of Diverse Economic Status and} Different Genders

Graduate employment outcomes are linked to social capital. Social capital is defined as a person's network ties to kin and friends (Coleman, 1990). People with enhanced social capital are more able to mobilize necessary network ties to achieve their goals (Hurlbert, 1991). 
Graduates of diverse economic status possess different volumes and values of social capital, differentiating their opportunities of achieving desirable employment outcomes (Moreau \& Leathwood, 2006).

Graduate gender is also linked to social capital and employment outcomes. Numerous families have traditionally favored sons over daughters, providing richer and more valuable social capital to sons (Eccles, 2011). In society, men often play core roles with access to higher rewards and enhanced opportunities, whereas women play peripheral roles with limited economic returns and social mobility (Lin, 2000). Women from poor families are thus positioned in a double-bind of subordinate status, both in family and society, and with scant social capital (Stromquist, 2004).

Despite their scant social capital, studies have found women to outperform men in career aspirations (Schoon \& Polek, 2011) and employability skills (Bakar \& Hanafi, 2007). Job opportunities in the labor market have been increasing for women, but decreasing for men (Danziger \& Ratner, 2010). However, a scrutiny of the job characteristics of both genders shows that women predominantly obtain jobs characterized as low expertise (Lucas, 1997). Female graduates receive a lower starting salary than males based on comparable college performances (Bobbitt-Zeher, 2007). Despite their worse employment circumstances, women perceive higher job satisfaction than do men (Clark, 1997). Gender difference on employment outcomes is a research arena not yet fully clarified.

\subsection{Collegiate Experience of Graduates of Diverse Economic Status}

Higher education can be divided into two tracks: general versus technical (or vocational) education. Higher institutes of technical education stress cultivating employment-ready graduates (Ziderman, 1997) and have predominantly enrolled students of lower economic status who are strongly orientated to pursue a career (O'Connor et al., 2010; Wu, 2012). Correspondingly, graduates of technical institutes have performed employability skills (Bakar \& Hanafi, 2007) and have been acknowledged by industries (Mustapha \& Greenan, 2002). In the 1990s, Asian developing countries such as Taiwan, South Korea, and Singapore extensively established technical institutes to massively produce a skilled workforce for industries (Tzannatos \& Johnes, 1997). In the academic year of 2014, technical institutes around Taiwan enrolled 659,001 students, accounting for $49.18 \%$ of all college students (Ministry of Education of Taiwan, 2016).

In college, students of low economic status often need to work part-time (Entwisle et al., 2000) because college is much more costly, compared to family annual income, for them than for their affluent counterparts (King, 2002). Although certain research has contended that a part-time job facilitates student career preparation, particularly for socioeconomically disadvantaged students (Riggert et al., 2006), the effect of a part-time job on graduate employment remains inconclusive (Tuttle et al., 2005). Student economic status also affects their leadership experience in college (Wu \& Bao, 2012), which is increasingly demanded by the workplace (Rahman et al., 2011). To smoothly transfer graduates to the workplace, colleges require empirical knowledge on how to prepare their graduates to meet workplace demands. 


\subsection{Work Motivation, Job Characteristics, and Employment Outcomes}

People work based on extrinsic and intrinsic motivations. Extrinsic work motivation is defined as working to attain instrumental rewards such as money or welfare, and intrinsic work motivation refers to inherent enjoyment such as independence and self-actualization (Ryan \& Deci, 2000). Research has shown that people of diverse economic status work for different motivations rooted in their values and needs (Wathington et al., 2011), which eventually lead them to different employment outcomes. Further, people tend to choose jobs with characteristics echoing their self-identities and career aspirations (Phillips \& Pittman, 2003). Family and school construct people's aspirations of what professional roles to play (Greenbank, 2009) and what employment outcomes to expect (Webbink \& Hartog, 2004).

Among numerous job characteristics, job expertise and experience are two major characteristics comprising a job description. College graduates who work jobs characterized as high expertise report better early employment outcomes and ultimate career success than those with low expertise jobs (Bynner, 1998). Job experience assists employees to effectively adapt to the rapidly changing workplace context (Cheung \& Aronld, 2010). Rich job experience has been found to benefit early employment outcomes for socioeconomically disadvantaged graduates who enter the workplace with fewer social resources (McGuinness \& Bennett, 2007).

Research on graduate employment should not be limited to addressing work opportunities, but should explore various employment outcomes to achieve a comprehensive understanding of graduate employment. An important debate of graduate employment is how employment is linked to, or freed from, graduate socioeconomic status (Schoon \& Polek, 2011). Research has found that graduate work opportunities are strongly linked to socioeconomic status, and graduates of lower socioeconomic status earn a lower salary than those of a higher socioeconomic status (Dreher \& Chargois, 1998). No research has yet analyzed and compared factors affecting different employment outcomes of graduates of diverse economic status. Incomprehensive understanding of graduate employment prohibits institutes from tailoring employment services specifically for graduates of diverse backgrounds.

\section{Research Method}

\subsection{Data Source}

This study derived data from the "Survey of College Graduates One-Year after Graduation", administrated by the Taiwan Integrated Post-Secondary Education Database (TIPED). The survey collected information of graduates' personal backgrounds, collegiate experiences, and early employment outcomes. TIPED conducted the survey in 2006, with the graduate cohort of 2005. TIPED first analyzed the 2005 graduate information compiled by the Ministry of Education of Taiwan, and then employed stratified random sampling to sample graduates from 140 higher institutes around Taiwan, with a ratio of $25 \%$ and at least 100 graduates per institute. TIPED administrated the survey through the Internet and retrieved 16,387 questionnaires, resulting in a $33.51 \%$ return rate, which approximated the average return rate of Internet surveys (Couper, 2000). All survey data were self-reported. Student self-report 
data reflect the firsthand experiences and direct perceptions of students, providing important information for educational improvement (Pike, 1995).

This study analyzed early employment outcomes and related factors of graduates of diverse economic status. The study split graduates into three levels of economic status based on their annual family incomes: low economic status of less than NT\$500,000 (NT\$30 approximates to US\$1), middle economic status of NT $\$ 510,000$ to $\$ 1,140,000$, and high economic status of NT $\$ 1,150,000$ and more. The proportions of graduates from the three economic status backgrounds were $25.1 \%, 45.4 \%$, and $29.5 \%$, respectively.

\subsection{Variables and Data Refinement}

The dependent variables of this study were employment outcomes, including job opportunity, salary, and job satisfaction. To enhance research reliability, this study refined TIPED data before analyzing them. Job opportunity in the study was operationally defined with one questionnaire item of "What is your current status?" with options of employed, unemployed, graduated student, and enlisted in the army. This study analyzed employment outcomes and excluded 7,006 cases identified as graduated students and enlisted. Salary was defined with one item of "What is your average monthly salary?" Responses to this question originally ranged from NT $\$ 0$ to $\$ 800,000$. The study employed the Inter-Quartile Range (IQR) (Upton \& Cook, 1996)

$$
\left[Q_{1}-k\left(Q_{3}-Q_{1}\right), Q_{3}+k\left(Q_{3}-Q_{1}\right)\right]
$$

to identify values outside the range as outliners and calculated a more reasonable range of salary of NT $\$ 11,600$ to $\$ 42,000 〔=23,000-1.5 \times(30,600-23,000), 30,600+1.5 \times$ $(30,600-23,000))$. Because no graduate reported salary of NT $\$ 11,600$, the least salary analyzed was NT\$12,000. Job satisfaction was defined with one item of "Are you satisfied with your job?" and coded as $1=$ yes and $0=$ no.

The independent variables of the study consisted of four blocks, namely gender, collegiate experience, work motivation, and job characteristics. Gender was categorized as male or female. Collegiate experience consisted of items of graduating from a technical or general institute, academic performance, part-time work, and a student leadership role at college. Work motivation was defined with a question section of "Please rate the listed considerations in choosing your job." The study grouped the considerations into extrinsic and intrinsic work motivations based on concepts of Ryan and Deci (2000). Extrinsic work motivation included money, welfare, and location. Intrinsic work motivation included promotion, responsibility, and independence. Job characteristics consisted of job expertise and job experience. Job expertise was defined with a question of "What level of education does your job require?" with a measurement scale ranging from below junior high school to $\mathrm{Ph} . \mathrm{D}$. The study recoded the scale into (college) degree-level versus non-degree job expertise. Job experience was defined with a question of "How much experience does your job require?" with a measurement scale ranging from no experience to more than 5 years of experience. Table 1 presents the measurement scales and operational definitions of the study variables. 


\subsection{Data Analysis}

For data analysis, descriptive analysis was conducted to answer Research Question (1) "What are the early employment outcomes of graduates of diverse economic status?" and (2) "What are the gender distribution, collegiate experience, work motivation, and job characteristics of graduates of diverse economic status? Regression analysis was conducted to answer Research Question (3) "How do gender, collegiate experience, work motivation, and job characteristics affect early employment outcomes of graduates of diverse economic status?"

\subsection{Research Limitation}

The database analyzed in this study and its application is limited. The data were collected 1 year after graduation when graduates were at an early stage of their career development. Applying the study results to the later career stages of graduates may be inappropriate. However, early employment outcomes are vital in reflecting education quality of institutes and indicating later career development of graduates (Saks \& Ashforth, 1999).

\section{Results}

\subsection{Early Employment Outcomes of Graduates of Diverse Economic Status}

Table 1 presents early employment outcomes of graduates of diverse economic status. The results showed that graduate salary and job satisfaction correspond to their economic status. The lower the economic status of graduates, the lower the salary (low $=26,642<$ middle $=$ $27,234<$ high $=27,883)$ and job satisfaction $($ low $=2.69<$ middle $=2.74<$ high $=2.76)$ they earned and perceived. The results did not show a correspondence between graduate job opportunity and economic status.

\subsection{Gender Distribution, Collegiate Experience, Work Motivation, and Job Characteristics of Graduates of Diverse Economic Status}

Table 1 shows that graduate gender distribution, collegiate experience, work motivation, and job characteristics largely correspond to economic status. Female percentage rose when graduate economic status fell (high $=52.48 \%<$ middle $=55.21 \%<$ low $=56.78 \%$ ). The lower the graduate economic status, the higher percentage of graduates studied in technical institutes (low $=54.50 \%>$ middle $=48.14 \%>$ high $=39.83 \%$ ), but fewer of them attained student leadership roles (low $=39.50 \%<$ middle $=43.07 \%<$ high $=45.36 \%$ ). More graduates of low and middle economic status worked part-time than did their counterparts of high economic status (low $=20.31 \%$ and middle $=20.38 \%>$ high $=18.01 \%$ ). Graduate academic performance at college did not consistently correspond to economic status.

Graduates across economic status showed a work motivation trend to place greater importance on extrinsic motivation than on intrinsic motivation. The lower the graduate economic status was, the greater importance they placed on extrinsic motivation of money $($ low $=3.31>$ middle $=3.26>$ high $=3.25)$, welfare $($ low $=3.39>$ middle $=3.35>$ high $=$ 3.33 ), and location (low $=3.09>$ high $=3.07>$ middle $=3.04)$.

Finally, the results showed that graduates' job characteristic of expertise corresponded to their economic status. The lower the graduate economic status was, the fewer of them that 
obtained degree-level jobs (low $=46.53 \%<$ middle $=47.93 \%<$ high $=51.55 \%$ ). Additionally, only half of the graduates in overall obtained degree-level jobs. The graduate job characteristic of experience did not correspond to economic status.

Table 1. Descriptive analysis of employment outcomes, gender, collegiate experience, work motivation, and job characteristics of graduates of diverse economic status

\begin{tabular}{|c|c|c|c|c|}
\hline & \multirow{3}{*}{$\begin{array}{c}\text { Score ranges and } \\
\text { operational definitions }\end{array}$} & \multicolumn{3}{|c|}{ Graduate economic status } \\
\hline & & Low & Middle & High \\
\hline & & \multicolumn{3}{|c|}{$\% / M(S D)$} \\
\hline \multicolumn{5}{|l|}{ Employment outcome } \\
\hline Job opportunity & 1/0: $1=$ employed, $0=$ unemployed & $76.73 \%$ & $76.96 \%$ & $74.96 \%$ \\
\hline Salary & NT\$12,000 - \$42,000 & 26,642 & 27,234 & 27,883 \\
\hline Job satisfaction & $1 / 0: 1=$ satisfied, $0=$ unsatisfied & $66.52 \%$ & $68.67 \%$ & $70.59 \%$ \\
\hline \multicolumn{5}{|l|}{ Gender } \\
\hline Female/Male & $1 / 0: 1=$ female, $0=$ male & $56.78 \%$ & $55.21 \%$ & $52.48 \%$ \\
\hline \multicolumn{5}{|l|}{ Collegiate experience } \\
\hline Technical institute & $\begin{array}{l}1 / 0: 1=\text { technical institute, } 0= \\
\text { general institute }\end{array}$ & $54.50 \%$ & $48.14 \%$ & $39.83 \%$ \\
\hline Academic performance & $\begin{array}{l}1-4: 1=60-69 \text { GPA, } 2=70-79 \text { GPA, } \\
3=80-89 \text { GPA, } 4=\text { above } 90 \text { GPA. }\end{array}$ & $2.47(.67)$ & $2.48(.67)$ & $2.45(.68)$ \\
\hline Part-time job & $1 / 0: 1=$ yes, $0=$ no & $20.31 \%$ & $20.38 \%$ & $18.01 \%$ \\
\hline Student leader & & $39.50 \%$ & $43.07 \%$ & $45.36 \%$ \\
\hline \multicolumn{5}{|l|}{ Extrinsic work motivation } \\
\hline Money & & $3.31(.60)$ & $3.26(.59)$ & $3.25(.62)$ \\
\hline Welfare & & $3.39(.58)$ & $3.35(.59)$ & $3.33(.61)$ \\
\hline Location & 1-4: $1=$ not important at all, $2=$ not & $3.09(.67)$ & $3.04(.69)$ & $3.07(.67)$ \\
\hline Intrinsic work motivation & very important, $3=$ important, $4=$ & & & \\
\hline Promotion & very important. & $3.05(.73)$ & $3.04(.70)$ & $3.08(.69)$ \\
\hline Responsibility & & $3.01(.62)$ & $2.98(.60)$ & $3.05(.59)$ \\
\hline Independence & & $3.02(.65)$ & $3.00(.63)$ & $3.03(.63)$ \\
\hline \multicolumn{5}{|l|}{ Job characteristics } \\
\hline Expertise & 1/0: $1=$ degree-level, $0=$ non-degree & $46.53 \%$ & $47.93 \%$ & $51.55 \%$ \\
\hline Experience & $\begin{array}{l}1-7: 1=\text { no need, } 2=\text { less than } 1 \\
\text { month, } 3=1-6 \text { months, } 4=6-12 \\
\text { months, } 5=1-3 \text { years, } 6=3-5 \text { years, } \\
7=\text { more than } 5 \text { years. }\end{array}$ & $3.23(1.46)$ & $3.31(1.42)$ & $3.28(1.43)$ \\
\hline
\end{tabular}

Note: Missing values were excluded from the calculations. 
4.3 Effects of Gender, Collegiate Experience, Work Motivation, and Job Characteristics on Early Employment Outcomes of Graduates of Diverse Economic Status

Table 2 shows the results of three early employment outcomes, namely job opportunity, salary, and job satisfaction. This study used logistic regression to analyze job opportunity and job satisfaction, showing the odds ratio $(O R)$ in Models 1 and 3. $O R>1$ represents a positive effect and $O R<1$ represents a negative effect. This study used linear regression to analyze salary, showing standard coefficients $(\beta)$ in Model 2. $\beta>0$ represents a positive effect and $\beta<$ 0 represents a negative effect.

\subsubsection{Effects on Job Opportunity}

Model 1 shows the effects of gender and collegiate experience on the job opportunity of graduates of diverse economic status. Work motivation and job characteristics did not apply to unemployed graduates and were not included in the model.

Gender showed consistent effects on the job opportunity of graduates across economic status, with a higher job opportunity for women than for men (low $O R=1.828, p<.05$; middle $O R$ $=2.378, p<.001$; high $O R=1.603, p<.05)$. Among collegiate experiences, technical institutes consistently affected the job opportunity of graduates across economic status. Technical institute graduates had approximately two times of job opportunities than general institute graduates across economic status (low $O R=2.342$, middle $O R=2.105$, high $O R=$ 2.102; $p<.001)$. Academic performance, part-time job, and student leadership role inconsistently affected the job opportunity of graduates of diverse economic status. Academic performance positively affected the job opportunity of low and high economic status graduates (low $O R=1.309, p<.05$; high $O R=1.425, p<.01$ ), but not middle economic status graduates. Part-time job (low $O R=1.882, p<.001$; middle $O R=1.407, p<.01$ ) and student leadership role (low $O R=1.446$, middle $O R=1.310 ; p<.05$ ) positively affected the job opportunity of low and middle economic status graduates, but not high economic status graduates.

\subsubsection{Effects on salary}

Model 2 shows the effects of gender, collegiate experience, work motivation, and job characteristics on the salary of graduates of diverse economic status. Gender consistently affected the salary of graduates across economic status, with women earning a lower salary than men (low $\beta=-.106, p<.05$; middle $\beta=-.111$; high $\beta=-.183, p<.001$ ).

Among collegiate experiences, technical institute graduates consistently earned a lower salary than general institute graduates across economic status (low $\beta=-.153$, middle $\beta=-.170$, high $\beta=-.153 ; p<.001)$. Academic performance $(\beta=.103, p<.01)$ and student leadership role $(\beta$ $=.060, p<.05)$ positively affected the salary of graduates of high and middle economic status, respectively, but not graduates of low economic status. Part-time job did not affect the salary of graduates across economic status.

Work motivation showed mixed effects on the salary of graduates of diverse economic status. Among extrinsic work motivations, money motivation benefited the salary of graduates of 
low and middle economic status (low $\beta=.152, p<.01$; middle $\beta=.127, p<.001$ ), and welfare motivation benefited the salary of graduates of high economic status $(\beta=.133, p$ $<.01)$. Among intrinsic work motivations, responsibility motivation disadvantaged the salary of graduates of high economic status $(\beta=-.103 ; p<.05)$.

Job characteristics of expertise and experience showed substantial effects on salary for most graduates. Jobs characterized as degree-level expertise benefited the salary of graduates across economic status (low $\beta=.196$, middle $\beta=.254$, high $\beta=.283 ; p<.001$ ), and job experience benefited the salary of graduates of low and middle economic status (low $\beta=.109$, $\mathrm{p}<.01$; middle $\beta=.144, \mathrm{p}<.001$ ).

Table 2. Regression analyses of related factors on the early employment outcome of graduates of diverse economic status

\begin{tabular}{|c|c|c|c|c|c|c|c|c|c|}
\hline & \multicolumn{3}{|c|}{ Model 1} & \multicolumn{3}{|c|}{$\begin{array}{c}\text { Model } 2 \\
\text { Salary }(\beta)\end{array}$} & \multicolumn{3}{|c|}{$\begin{array}{c}\text { Model } 3 \\
\text { Job satisfaction }(O R) \\
\end{array}$} \\
\hline & Low & Middle & $\frac{(O R)}{\text { High }}$ & Low & Middle & High & Low & Middle & High \\
\hline \multicolumn{10}{|l|}{ Gender } \\
\hline Female & $1.828 *$ & $2.378 * * *$ & $1.603^{*}$ & $-.106 * *$ & $-.111 * * *$ & $-.183 * * *$ & 1.039 & .996 & 1.300 \\
\hline \multicolumn{10}{|c|}{ Collegiate Experience } \\
\hline $\begin{array}{l}\text { Technical } \\
\text { institute }\end{array}$ & $2.342 * * *$ & $2.105 * * *$ & $2.102 * * *$ & $-.153 * * *$ & $-.170 * * *$ & $-.153 * * *$ & .760 & .770 & 1.112 \\
\hline $\begin{array}{l}\text { Academic } \\
\text { performance }\end{array}$ & $1.309 *$ & 1.161 & $1.425 * *$ & .058 & .052 & $.108 * *$ & .958 & .866 & .849 \\
\hline Part-time job & $1.882 * * *$ & $1.407 * *$ & 1.095 & -.018 & -.048 & -.050 & $.641 *$ & .846 & .749 \\
\hline Student leader & $1.446 *$ & $1.310 *$ & 1.157 & -.039 & $.055 *$ & .027 & .992 & 1.026 & .976 \\
\hline \multicolumn{10}{|l|}{$\begin{array}{l}\text { Extrinsic work } \\
\text { motivation }\end{array}$} \\
\hline Money & & & & $.152 * *$ & $.127 * * *$ & .011 & 1.061 & .883 & .986 \\
\hline Welfare & & & & .001 & -.003 & $.133 * *$ & $.673 *$ & .774 & .815 \\
\hline Location & & & & .039 & -.050 & .035 & $1.449 * *$ & .893 & 1.043 \\
\hline \multicolumn{10}{|l|}{$\begin{array}{l}\text { Intrinsic work } \\
\text { motivation }\end{array}$} \\
\hline Promotion & & & & -.012 & -.052 & -.059 & .885 & $.695 * *$ & $.729 *$ \\
\hline Responsibility & & & & -.079 & -.008 & $-.103 *$ & 1.146 & 1.272 & 1.235 \\
\hline Independence & & & & .013 & .010 & .052 & 1.100 & $1.385^{*}$ & 1.116 \\
\hline \multicolumn{10}{|l|}{ Job characteristics } \\
\hline Expertise & & & & $.196 * * *$ & $.254 * * *$ & $.283 * * *$ & $3.218 * * *$ & $2.354 * * *$ & $2.492 * * *$ \\
\hline Experience & & & & $.123 * *$ & $.138 * * *$ & .056 & $1.171 *$ & $1.147 * *$ & 1.127 \\
\hline $\begin{array}{l}\text { Nagelkerke } R^{2} / \text { Adj. } \\
R^{2}\end{array}$ & .105 & .081 & .067 & .129 & .192 & .173 & .177 & .134 & .102 \\
\hline
\end{tabular}

Notes: $*=p<.05, * *=p<.01, * * *=p<.001$ 


\subsubsection{Effects on Job Satisfaction}

In Model 3, gender and most collegiate experiences show no significant effect on job satisfaction, except for the negative effect of part-time job on the job satisfaction of graduates of low economic status $(O R=.641, p<.05)$.

Work motivation exerted mixed effects on job satisfaction. Among extrinsic motivations, welfare hindered $(O R=.673 ; p<.05)$, but location enhanced $(O R=1.449 ; p<.05)$ the job satisfaction of graduates of low economic status. Among intrinsic motivations, promotion hindered the job satisfaction of graduates of middle $(O R=.695, p<.01)$ and high $(O R=.729$, $p<.05$ ) economic status, whereas independence enhanced the job satisfaction of graduates of middle economic status $(\mathrm{OR}=1.385 ; \mathrm{p}<.05)$.

Job characteristics of expertise and experience showed substantial effects on job satisfaction for most graduates. All graduates with jobs characterized as degree-level expertise were two to three times more likely to perceive job satisfaction than were their counterparts with jobs characterized as non-degree expertise (low $O R=3.218$, middle $O R=2.354$, high $O R=2.492$; $p<.001)$. Job experience enhanced the job satisfaction of low and middle economic status (low $O R=1.171, p<.05$; middle $O R=1.147, p<.001$ ). A close comparison of the regression coefficients of job expertise and experience on salary and job satisfaction shows that, expertise resulted in higher and more extensive benefits to salary and job satisfaction of graduates across economic status.

\section{Discussion and Conclusion}

In response to Research Question 1 "What are the early employment outcomes of graduates of diverse economic status?" the study showed that the graduates' early employment outcomes of salary and job satisfaction corresponded to their economic status. The poorer (lower economic status) the graduates, the lower their salary and job satisfaction was. This meaningful result is possibly explained by the different financial needs and the social capital possessed by graduates of diverse economic status. Previous research has noted that affluent graduates are advantaged by fewer financial needs but richer social capital (Moreau \& Leathwood, 2006; Schoon et al., 2007), allowing them to choose jobs until they find one with a good salary and satisfactory conditions. By contrast, poor graduates are not only disadvantaged by higher financial needs and less social capital, but are also unable to access critical employment knowledge (Greenbank, 2009). Consequently, they cannot afford to be choosy for employment and may often hastily settle for jobs with an unsatisfactory salary and conditions. This study urges institutes to strengthen campus-based employment services and consultations targeting poor graduates to encourage these graduates to obtain not any job, but a satisfactory one.

In response to Research Question 2 "What are the gender distribution, collegiate experience, work motivation, and job characteristics of graduates of diverse economic status?" the study results showed that graduate gender distribution, collegiate experience, work motivation, and job characteristics substantially corresponded to their economic status. Women accounted for the highest percentage among the poorest graduates. Positioned in a 
double-bind subordination of being female and poor, poor women possess the least quantity and quality of social capital, compared to their counterparts (Eccles, 2011; Lin, 2000; Stromquist, 2004). To poor women wishing to change their subordinate position, education serves as a precious capital alternative. Poor women could thus be more persistent in completing college education than their counterparts.

For collegiate experience, work motivation, and job characteristics, the study showed that poor graduates mostly studied in technical institutes, placed the greatest importance on the work motivation of money, and were mostly employed with non-degree jobs. The results that poor graduates mostly studied in technical institutes found by this study and other studies (O'Connor et al., 2010; $\mathrm{Wu}, 2012$ ) indicates a parallel between education tracking and socioeconomic status. The money-motivation emphasis of these poor graduates suggests that they choose technical institutes that stress employment preparation (Ziderman, 1997) to obtain desirable jobs, wishing to relieve their financial pressure and to hopefully upgrade their socioeconomic status. Unfortunately, because job upgrading rarely occurs for graduates with non-degree jobs (Battu et al., 2000), most poor graduates probably persist, rather than upgrade, their subordinate socioeconomic status.

The strong tendency of the poor graduates to work under their degree not only can be retraced to their meager social capital, but to their inferior self-identity (Phillips \& Pittman, 2003) or career aspiration (Cheung \& Arnold, 2010). Poor graduates who grow up with family members working as non-degree blue collars naturally associate their self-identity and career aspiration with non-degree occupations. Future research seeking to disentangle the associations of socioeconomic status, self-identity, career aspirations, and employment outcomes is in demand. Such research would shed light on theoretical analyses and practical interventions in facilitating the employment behaviors and outcomes of socioeconomically disadvantaged graduates.

In response to Research Question 3 "How do gender, collegiate experience, work motivation, and job characteristics affect the early employment outcomes of graduates of diverse economic status?" this study shows prominent results which are highlighted in bold as follows. For gender and institutional types, the study found that women and technical graduates were advantaged for job opportunity, disadvantaged for salary, but approximate for job satisfaction compared to their counterparts. The result is partially supported by previous research that has found that women are having more job opportunities (Danziger \& Ratner, 2010) but still earning less salary than their comparable male counterparts (Bobbitt-Zeher, 2007). The study concurs with Clark's argument (1997) that the results may reflect the lower employment expectation of women and technical graduates. Because of their lower employment expectation, these graduates may be more willing to accept a wider range of job opportunities, but on average earn a lower salary, and still perceive the same approximate job satisfaction as their counterparts. This study suggests institutes wishing to improve the salary of women and techinical graduates to first elevate these graduates' employment expectations.

Collegiate experience exhibited pronounced benefits to the job opportunity of poor 
graduates, but not to affluent graduates. The pronounced benefits of collegiate experience to poor graduates are likely because that collegiate experience adds particular value to the social capital of socioeconomically disadvantaged students (Moreau \& Leathwood, 2006; Schoon et al., 2007). A part-time job and student leadership roles at college were found to enhance student social networks (Entwisle et al., 2000; Riggert et al., 2006) and social status (Wu \& Bao, 2012), adding notable value to the meager social capital of poor students. This study thus suggests that institutes highlight the particular benefits of collegiate experiences on job opportunities of poor students to encourage their active collegiate involvement.

Extrinsic and intrinsic work motivations showed mixed effects on the salary of graduates of diverse economic status. These effects were scattered over graduates of diverse economic status, preventing the study to induce conclusive findings. The influences of motivations on employment outcomes, although fundamental, may emerge slowly and require extended periods of observation to detect (Malka and Chatman, 2003). The early employment stage is perhaps insufficient for detecting the influences of motivations, and longitudinal data are required in future research.

Job characteristics of degree-level expertise substantially enhanced salary and job satisfaction for all graduates. A close comparison of the regression coefficients of job characteristics of expertise and experience shows that expertise resulted in higher and more extensive benefits to salary and job satisfaction of graduates across economic status. This is likely because these graduates are in their early career stage and have mostly worked clerical positions where expertise is more valued than experience (Mason, 2002). When competing for clerical positions with a higher salary and better conditions, all graduates equipped with additional credentials or certifications can readily substantiate their degree-level expertise and out-compete their competitors. Degree-level expertise thus substantially and extensively enhances salary and job satisfaction of all graduates. Institutes hoping to advance the early employment outcomes of most graduates may want to emphasize their graduates' expertise, and encourage their graduates to acquire additional credentials and certificates. Meanwhile, research investigating whether the comparative effects of expertise and experience evolve with graduate career development is needed.

In conclusion, graduate employment has emerged as a critical issue for numerous interest groups, attracting extensive attention and generating heated debates. Previous literature has typically addressed single employment outcome and treated graduates as one unity, compromising the comprehensive understanding of various employment problems encountered by graduates of diverse socioeconomic backgrounds. This study adds to the literature by showing that graduate salary and job satisfaction correspond to economic status. Collegiate experience enhances the job opportunity of poor graduates the most, whereas job expertise enhances the salary and job satisfaction of all graduates. This study further contributes to institutional practices by suggesting that employment interventions should be tailored for graduates of diverse economic status. Future research analyzing the longitudinal employment process of graduates of diverse socioeconomic backgrounds is required for scholars and educators to continuously pursue successful school-to-workplace transitions. 


\section{References}

Astin, A. W., \& Oseguera, L. (2004). The declining" equity" of American higher education. Review of Higher Education, 27(3), 321-342.

Bakar, A. R., \& Hanafi, I. (2007). Assessing employability skills of technical-vocational students in Malaysia. Journal of Social Sciences, 3(4), 202-207.

Battu, H., Belfield, C. R., \& Sloane, P. J. (2000). How well can we measure graduate over-education and its effects? National Institute Economic Review, 171(1), 82-93.

Bobbitt-Zeher, D. (2007). The gender income gap and the role of education. Sociology of Education, 80(1), 1-22. http://dx.doi.org/10.1177/003804070708000101

Bynner, J. (1998). Education and family components of identity in the transition from school to work. International Journal of Behavioral Development, 22(1), 29-53. http://dx.doi.org/10.1080/016502598384504

Cheung, R., \& Arnold, J. (2010). Antecedents of career exploration among Hong Kong Chinese university students: Testing contextual and developmental variables. Journal of Vocational Behavior, 76(1), 25-36.

Clark, A. E. (1997). Job satisfaction and gender: Why are women so happy at work? Labour Economics, 4(4), 341-372. http://dx.doi.org/10.1016/s0927-5371(97)00010-9

Coleman, J. S. (1990). Foundations of Social Capital Theory. Cambridge, MA: The Belkamp Press of Harvard University Press.

Couper, M. P. (2000). Web surveys: A review of issues and approaches. Public Opinion Quarterly, 64(4), 464-494.

Danziger, S., \& Ratner, D. (2010). Labor market outcomes and the transition to adulthood. The Future of Children, 133-158.

Directorate General of Budget of Taiwan. (2015). Statistic analysis of employment of December 2015. Retrieved from http://www.wda.gov.tw/home.jsp?pageno=201112080003\& acttype $=$ view $\&$ dataserno $=201601140003$

Dreher, G. F., \& Chargois, J. A. (1998). Gender, mentoring experiences, and salary attainment among graduates of an historically black university. Journal of Vocational Behavior, 53(3), 401-416.

Eccles, J. (2011). Gendered educational and occupational choices: Applying the Eccles et al. model of achievement-related choices. International Journal of Behavioral Development, 35(3), 195-201. http://dx.doi.org/10.1177/0165025411398185

Entwisle, D. R., Alexander, K. L., \& Olson, L. S. (2000). Early work histories of urban youth. American Sociological Review, 65, 279-297.

Freund, A. M. (2011). Introduction to the special section: The role of gender in school-related transitions and beyond. International Journal of Behavioral Development, 35(3), 193-194. 
Greenbank, P. (2009). An examination of the role of values in working-class students' career decision-making. Journal of Further and Higher Education, 33(1), 33-44.

Haveman, R. H., \& Smeeding, T. M. (2006). The role of higher education in social mobility. The Future of Children, 16(2), 125-150. http://dx.doi.org/10.1353/foc.2006.0015

Hirsch, B., \& Schnabel, C. (2010). Women move differently: Job separations and gender. Journal of Labor Research, 33(4), 417-442.

Hurlbert, J. S. (1991). Social networks, social circles, and job satisfaction. Work and Occupations, 18(4), 415-430. http://dx.doi.org/10.1177/0730888491018004003

ILO. (2014). Global Employment Trends for Youth 2015: Scaling up investments in decent jobs for youth. Retrieved from http://www.ilo.org/global/research/global-reports/youth/2015/lang--en/index.htm

King, J. E. (2002). Crucial choices: How students' financial decisions affect their academic success. Washington, DC: American Council on Education, Center for Policy Analysis.

Kruss, G. (2004). Employment and employability: Expectations of higher education responsiveness in South Africa. Journal of Education Policy, 19(6), 673-689.

Liu, X., Thomas, S., \& Zhang, L. (2010). College quality, earnings, and job satisfaction: Evidence from recent college graduates. Journal of Labor Research, 31(2), 183-201.

Lucas, R. (1997). Youth, gender and part-time work: Students in the labour process. Work, Employment \& Society, 11(4), 595-614.

Malka, A., \& Chatman, J. A. (2003). Intrinsic and extrinsic work orientations as moderators of the effect of annual income on subjective well-being: A longitudinal study. Personality and Social Psychology Bulletin, 29(6), 737-746.

Mason, G. (2002). High skills utilisation under mass higher education: graduate employment in service industries in Britain. Journal of Education and Work, 15(4), 427-456.

McGuinness, S., \& Bennett, J. (2007). Overeducation in the graduate labour market: A quantile regression approach. Economics of Education Review, 26(5), 521-531.

Ministry of Education of Taiwan (2016). Statistic analysis of higher institutes of the academic year of 2014. Retrieved from https://stats.moe.gov.tw/

Moreau, M. P., \& Leathwood, C. (2006). Graduates' employment and the discourse of employability: A critical analysis. Journal of Education \& Work, 19(4), 305-324. http://dx.doi.org/10.1080/13639080600867083

Mustapha, R. B., \& Greenan, J. P. (2002). The role of vocational education in economic development in Malaysia: Educators' and employers' perspectives. Journal of Industrial Teacher Education, 39(2), 58-73.

Newton, J., \& Turale, S. (2000). Student poverty at the University of Ballarat. Australian Journal of Social Issues, 35(3), 251-266. 
O’Connor, N., Hammack, F., \& Scott, M. (2010). Social capital, financial knowledge, and hispanic student college choices. Research in Higher Education, 51(3), 195-219. http://dx.doi.org/10.1007/s11162-009-9153-8

Phillips, T. M., \& Pittman, J. F. (2003). Identity processes in poor adolescents: Exploring the linkages between economic disadvantage and the primary task of adolescence. Identity: An International Journal of Theory and Research, 3(2), 115-129. http://dx.doi.org/10.1207/S1532706XID030202

Pike, G. R. (1995). The relationship between self reports of college experiences and achievement test scores. Research in Higher Education, 36(1), 1-21.

Rahman, S., Mokhtar, S. B., \& Hamzah, R. M. Y. M. I. M. (2011). Generic skills among technical students in Malaysia. Procedia - Social and Behavioral Sciences, 15, 3713-3717. http://dx.doi.org/10.1016/j.sbspro.2011.04.361

Riggert, S. C., Boyle, M., Petrosko, J. M., Ash, D., \& Rude-Parkins, C. (2006). Student employment and higher education: Empiricism and contradiction. Review of Educational Research, 76(1), 63-92.

Ryan, R. M., \& Deci, E. L. (2000). Intrinsic and extrinsic motivations: Classic definitions and new directions. Contemporary educational psychology, 25(1), 54-67.

Saks, A. M., \& Ashforth, B. E. (1999). Effects of individual differences and job search behaviors on the employment status of recent university graduates. Journal of Vocational Behavior, 54(2), 335-349.

Schoon, I., \& Polek, E. (2011). Teenage career aspirations and adult career attainment: The role of gender, social background and general cognitive ability. International Journal of Behavioral Development, 35(3), 210-217. http://dx.doi.org/10.1177/0165025411398183

Schoon, I., Martin, P., \& Ross, A. (2007). Career transitions in times of social change. His and her story. Journal of Vocational Behavior, 70(1), 78-96.

Stromquist, N. P. (2004). Inequality as a way of life: Education and social class in Latin America. Pedagogy, Culture and Society, 12(1), 95-119.

Tuttle, T., McKinney, J., \& Rago, M. (2005). College students working: The choice nexus. IPAS Topics Brief, 1-11.

Tzannatos, Z., \& Johnes, G. (1997). Training and skills development in the East Asian newly industrialised countries: A comparison and lessons for developing countries1. Journal of Vocational Education and Training, 49(3), 431-453.

Upton, G., \& Cook, I. (1996). Understanding Statistics. Oxford: Oxford University Press.

Wathington, H. D., Pretlow, J., \& Mitchell, C. (2011). How does money help? Students' perceptions of the effect of a monetary incentive on completion of a summer bridge program. Enrollment Management Journal, 5(4), 45-66. 


\section{Macrothink}

International Research in Education

ISSN 2327-5499

2017, Vol. 5, No. 1

Webbink, D., \& Hartog, J. (2004). Can students predict starting salaries? Yes! Economics of Education Review, 23(2), 103-113.

Wu, C. L. (2012). A comparison of the effects of university learning experiences on student leadership at Taiwanese general and technical universities. The Asia-Pacific Education Researcher, 21(1), 130-140.

Wu, C. L., \& Bao, W. (2012). The effects of individual characteristics, socioeconomic status, and political engagement on the attainment of student leadership roles in Chinese university students. International Journal of Educational Development, 33(2), 149-155. http://dx.doi.org/10.1016/j.ijedudev.2012.03.004

Ziderman, A. (1997). National programmes in technical and vocational education: Economic and education relationships. Journal of Vocational Education and Training, 49(3), 351-366.

Zimmer-Gembeck, M. J., \& Mortimer, J. T. (2006). Adolescent work, vocational development, and education. Review of Educational Research, 76(4), 537-566.

\section{Copyright Disclaimer}

Copyright reserved by the authors.

This article is an open-access article distributed under the terms and conditions of the Creative Commons Attribution license (http://creativecommons.org/licenses/by/3.0/). 